\title{
Empirical Safety Thresholds for Liquidity and Indebtedness Ratios on the Polish Capital Market

\author{
Jacek Welc*
}

\begin{abstract}
:
One of the elements of company's evaluation is ratio analysis. It includes computation of bankruptcy risk metrics. There are multiple such measures, of which two seem to be quite universal and commonly applied. These are current ratio and indebtedness ratio. In this study, the accuracy of bankruptcy predictions based on these two ratios is evaluated within a sample of data from the Polish market. Also, the safety thresholds (meant as values at which the probability of bankruptcy exceeds fifty percent) are estimated. The study is based on a sample of 84 companies, in which case a bankruptcy filing was announced in a period between the beginning of 2009 and the end of the first half of 2015. This sample of bankrupt firms is compared to the counter-sample of companies in which case no any bankruptcy filing occurred. The statistical analysis has confirmed the usefulness of both ratios. Even though the sample covers wide variety of businesses, the logit models with only one ratio used as an explanatory variable are capable of identifying bankrupt firms in about $70-73 \%$ of cases. Our research has also shown that the estimated safety thresholds lie near the typically assumed "rules of thumb".
\end{abstract}

Key words: Bankruptcy prediction; Ratio analysis; Fundamental analysis; Financial liquidity; Current ratio; Indebtedness ratio.

JEL classification: G32, G33.

\section{Introduction}

One of the crucial elements of company's fundamental analysis, both for equity investment decisions as well as for credit risk evaluation, is ratio analysis. Typically, it is based on a set of financial ratios, computed on the ground of numbers reported in financial statements of an investigated firm. Those ratios are intended to quantify various aspects of a company's economic effectiveness and financial safety, such as profitability, long-term solvency, short-term liquidity and managerial effectiveness. An important part of the ratio analysis is a computation and interpretation of several metrics aimed at measuring the risk of company's bankruptcy. There are multiple such measures, of which two seem to be quite universal and commonly applied. These are:

Jacek Welc; Wroclaw University of Economics, Department of Regional Economics, Nowowiejska 3, 58-500 Jelenia Gora, Poland, <jacek.welc@ue.wroc.pl>. 

Market.

- current ratio, aimed at quantifying the company's short-term financial liquidity,

- total indebtedness ratio, intended to measure the firm's long-term solvency.

Current ratio is usually computed as a quotient of company's total current assets to its total current liabilities. Total indebtedness ratio, in turn, divides total liabilities (including provisions) by total assets. Computation of both ratios, in their most commonly met forms, is based on carrying amounts (and not fair values) of assets and liabilities, as reported in the company's balance sheet. Thus, one of the main advantages of both ratios is its simplicity and easiness of computation. However, it is also an important drawback, because in the case of both ratios the structure of company's assets (e.g. share of receivables or inventories in current assets or share of intangibles in total assets) is not taken into consideration.

In a financial statement analysis, the current and indebtedness ratios of a given enterprise are typically evaluated either by comparing their values to some industry standards (e.g. averages for the companies from the same industry) or to some subjective thresholds (so called "rules of thumb"). Both of these approaches have their pros and cons. The major benefit of intra-industry comparisons is a reference to a sample of firms which are deemed similar (in terms of business profiles) and comparable, e.g. to competitors of an investigated company. However, such approach is prone to inference distortions caused by possible industry-wide biases. For example, when majority of firms in a given industry tend to be over-indebted, then the intra-industry comparison may pick the overindebted firm as financially sound, only because its indebtedness ratio lies below an industry-average (even though it may be on a hazardous level). Also, for some companies with very specific (e.g. specialized) operations the reliable industry averages may be unavailable (which results in comparing a given firm's ratios to benchmarks computed for the sample of incomparable firms). Those drawbacks are absent in an analysis based on "rules of thumb", where computed values of ratios are compared to some pre-assumed universal safety thresholds. However, this approach has its own serious flaws. First, it boils down to assuming similar benchmarks for companies operating in various industries, while in reality some of them may afford more indebtedness and lower current liquidity, due to their relatively low operating risks, while others should follow more conservative financial strategies to stay solvent. Second, the "rules of thumb" usually suggest some subjective values of ratios as safety thresholds, without confirming them by any up-to-date empirical research, based on real-life data of enterprises operating in a broad spectrum of industries. Both discussed analytical approaches are vulnerable to another significant problem, which is a possible distortion of computed ratios stemming from objective differences in accounting policies followed by individual companies or from outright accounting manipulations (i.e. 
deliberate application of accounting gimmicks aimed at keeping some ratios at specific levels).

This research attempts to empirically examine an extent to which the last two of the above-mentioned problems, that is the subjectivity and uniformity of the "rules of thumb" as well as possible distortions resulting from inter-company differences in accounting principles, may limit the usefulness of liquidity and indebtedness ratios in predicting company failures. To this end, the accuracy of bankruptcy predictions based on current ratio and total indebtedness ratio is evaluated within a sample of real-life data from the Polish capital market. Then, after confirming the general usefulness of both metrics in credit risk analysis, the empirical safety thresholds (meant as values of ratios at which the probability of bankruptcy exceeds fifty percent) are estimated. The study is based on a sample of 84 public companies (whose shares or debt instruments have been traded on the Polish capital market), operating in broad spectrum of industries, in which case a bankruptcy filing was announced in a period between the beginning of 2009 and the end of the first half of 2015 (labelled as "bankrupt firms"). This sample of bankrupt firms is compared to the counter-sample of randomly selected nonbankrupt public companies (labelled as "healthy firms"), in which case no any bankruptcy filing occurred in 2009-2015 period.

The remainder of the paper is organized as follows. In the next section the relevant literature is discussed. Next the data and methodology used in the study are described. Then the section that presents the empirical findings follows. The paper closes with concluding comments.

\section{Literature review}

\subsection{Nature and content of liquidity and indebtedness ratios}

Liquidity analysis measures the adequacy of a firm's cash resources to meet its near-term cash obligations, while solvency (indebtedness) analysis examines the firm's capital structure, including the mix of its financing sources and the ability of the firm to satisfy its longer-term debt and investment obligations (White et al., 2003). Liquidity and indebtedness ratios are complementary (rather than competitive) to each other, but may differ in terms of relative usefulness in various circumstances. For example, liquidity is more informative of credit risk for firms with high levels of short-term assets and liabilities (e.g. in inventory-intensive industries), since the operations and cash flows of those firms tend to be driven by short-term accounts (Demerjian, 2007). In contrast, total indebtedness may be more relevant in capital-intensive industries, where fixed (long-term) assets play a major role. 
Welc, J.: Empirical Safety Thresholds for Liquidity and Indebtedness Ratios on the Polish Capital Market.

Current ratio, defined as current assets divided by current liabilities, constitutes the most commonly used short-term liquidity ratio (Pratt - Niculita, 2008). According to Fridson and Alvarez (2002), illiquidity manifests itself as an excess of current cash payments due over cash currently available, and the current ratio gauges the risk of this occurring by comparing the claims against the company that will become payable during the current operating cycle (current liabilities) with the assets that are already in the form of cash or that will be converted to cash during the current operating cycle (current assets). Indebtedness or leverage (total liabilities divided by total assets), is in turn interpreted as a measure of the debt to be repaid relative to the total assets of the firm available as a source for repaying the debt (Beaver et al., 2005). Of the various balance sheet ratios designed to measure the long-term adequacy of the company's capital structure, the total-debtto-total-assets ratio probably is the most popular one (Pratt - Niculita, 2008).

Current ratios and indebtedness ratios are applied not only in a purely financial analysis (e.g. in equity valuation and credit risk assessment), but also in a corporate strategy analysis, planning and management (Wheelen - Hunger, 1995; White 2004; David 2011).

\subsection{Safety thresholds for liquidity and indebtedness ratios}

In a legendary textbook of Graham and Dodd (1934), a minimum ratio of quick assets to current liabilities, equalling two, is mentioned as a standard for industrial companies. However, these authors suggest an additional "rule of thumb", according to which the current assets exclusive of inventories should at least equal to the current liabilities (which implies a current ratio exceeding unity by some significant margin). The current ratio greater than two still constitutes an element of many stock investment strategies (Montier, 2009).

Nowadays, banks, suppliers and others that extend short-term credit to firms generally prefer a current ratio substantially in excess of unity (Stickney et al., 2004). If the current ratio is below unity, then fixed assets are being financed partially by short-term borrowings or by a negative working capital, which can be dangerous (Verninmen et al., 2005). However, a firm can face short-term liquidity problems even with the current ratio exceeding one by sizeable margin, when some of its current assets are not easy to liquidate (Palepu et al., 2004).

However, safety thresholds for current ratio may differ significantly between industries and individual companies, because of the differences in marketability of their short-term non-cash assets. Even in the oldest textbooks it is noted that the more easily current assets are convertible into cash, the less need be the proportion of current assets to current liabilities (Saliers, 1924). According to Moyer, McGuigan and Kretlow (1995), many practitioners view a current ratio of 1,5 as 
satisfactory for industrial firms, while public utilities may function with considerably lower ratios, because their accounts receivable turn over on a monthly basis, that is much faster than in the typical industrial firm. Retail stores may keep even lower ratios as they distribute fast-moving finished goods (which implies no necessity of holding any raw materials or semi-processed goods) and generate mostly cash sales. Thus, different types of businesses require different current ratios (Atrill, 2000). However, the inter-company variations in safety thresholds are not merely driven by business profiles, but also by other risk factors, such as company size. This is so because larger companies may have more potential funding sources, including public capital and money markets, which may reduce the size of the liquidity buffer needed, as compared to smaller companies without such access (Robinson et al., 2012).

In contrast to liquidity ratios, the literature is more silent on optimal or safe values for total indebtedness. It is obvious, however, that relatively high financial leverage may be more affordable in the case of companies with relatively low operating risks (i.e. low demand cyclicality, low operating leverage, stable sale prices, etc.), while firms operating in more turbulent economic environments (e.g. construction companies, real estate developers or car manufacturers) should follow more prudent and conservative financing structures (with higher share of equity in total assets). However, according to the author's observations from the Polish capital market, the subjective general safety thresholds between $60 \%$ a $66 \%$ are often assumed for the share of total liabilities and provisions to total assets.

\subsection{Comparability and reliability of liquidity and indebtedness ratios in bankruptcy prediction}

Reliability and inter-company comparability of liquidity and indebtedness ratios may be distorted by accounting policy choices as well as by operating and financial decisions. For example, current ratio over the term of the lease is lower under the capital lease approach than it would be under the operating lease approach (Revsine et al., 2002). The inventory cost flow methods (e.g. FIFO vs. LIFO or weighted-average) as well as subjective judgments required under IFRS for classifying some assets and liabilities (into long-term or short-term categories) may also affect the comparability and reliability of reported current assets and liabilities (Mackenzie et al., 2012). Finally, in an effort to appear less risky and to lower their cost of capital, firms often attempt to structure financing in a manner that keeps debt off-balance sheet, e.g. through operating leases instead of capital ones (Ketz, 2003; Stickney et al., 2004; Giroux 2004). Kraft (2015) found that in a broad sample of companies reporting under US GAAP, the leverage ratio adjusted for off-balance sheet liabilities exceeds the reported leverage ratio by at least $20 \%$, on average. 

Market.

However, despite these common distortions and drawbacks of liquidity and indebtedness ratios, they appear statistically significant in huge majority of statistical models for bankruptcy prediction (Charalambous et al., 2000; Caouette et al., 2008). Particularly, those models usually include a total indebtedness ratio, meant as total liabilities divided by total assets, which often turns out to be the most statistically significant of all accounting ratios tested (Ohlson, 1980; Zmijewski, 1984; Shumway, 2001; Chava - Jarrow, 2004; Beaver et al., 2005).

\section{Data and Research Methods}

In this research the company data from a period between the beginning of 2009 and the end of the first half of 2015 have been used. The study covered public firms whose stocks or corporate bonds were listed on the Warsaw Stock Exchange (on the regulated market as well as on NewConnect and Catalyst) during those years. Within this timeframe, as many as 84 public firms faced at least one bankruptcy filing. The companies included in that sample, labelled further as "bankrupt firms", form the primary sub-sample. To enable a statistical analysis of the usefulness of investigated ratios in predicting corporate bankruptcy, the total sample has been extended by adding 84 randomly selected firms, in which case no any bankruptcy filing was announced in the same period (this sub-sample is further denoted as "healthy firms"). All the accounting numbers used in this study have been collected from primary sources, that is from annual reports issued by the companies included in the sample.

Only a one-period-ahead bankruptcy prediction horizon has been investigated. However, to make sure that only data which were publicly available on the bankruptcy filing date are taken into account, the following rules for data collection have been followed:

- For bankruptcy filings announced between the beginning of April and the end of December of $t$-th year (i.e. when annual financial statements for the preceding year have already been published), data from annual reports for $t-1$ period have been used,

- For bankruptcy filings announced between the beginning of January and the end of March of $t$-th year, data from annual reports for $t$ - 2 period have been used.

Table 1 provides a breakdown of the whole sub-sample of bankrupt firms by their industry memberships, while Table 2 displays a time-series distribution of the underlying bankruptcy filings. 
Tab. 1: Breakdown of investigated bankruptcy filings by industry memberships

\begin{tabular}{|c|c|c|}
\hline Industry & $\begin{array}{l}\text { Number of } \\
\text { observations }\end{array}$ & $\begin{array}{l}\text { Share in } \\
\text { a sample }\end{array}$ \\
\hline Construction \& Engineering & 16 & $19,0 \%$ \\
\hline IT technologies & 9 & $10,7 \%$ \\
\hline Distribution of foodstuffs & 6 & $7,1 \%$ \\
\hline Real estate investments & 5 & $6,0 \%$ \\
\hline Energy & 4 & $4,8 \%$ \\
\hline Financial services & 4 & $4,8 \%$ \\
\hline Manufacture of industrial goods & 4 & $4,8 \%$ \\
\hline Restaurants & 4 & $4,8 \%$ \\
\hline Distribution of software and hardware & 3 & $3,6 \%$ \\
\hline Distribution of vehicles and car parts & 3 & $3,6 \%$ \\
\hline Apparel stores & 2 & $2,4 \%$ \\
\hline Distribution of heavy industrial goods & 2 & $2,4 \%$ \\
\hline Distribution of other consumer goods & 2 & $2,4 \%$ \\
\hline Food production & 2 & $2,4 \%$ \\
\hline Manufacture of durable consumer goods & 2 & $2,4 \%$ \\
\hline Manufacture of glass products & 2 & $2,4 \%$ \\
\hline Manufacture of pharmaceuticals and cosmetics & 2 & $2,4 \%$ \\
\hline Manufacture of wood and wooden products & 2 & $2,4 \%$ \\
\hline Marketing services & 2 & $2,4 \%$ \\
\hline Waste management & 2 & $2,4 \%$ \\
\hline Distribution of medical equipment & 1 & $1,2 \%$ \\
\hline Distribution of pharmaceuticals & 1 & $1,2 \%$ \\
\hline Healthcare services & 1 & $1,2 \%$ \\
\hline Leisure services & 1 & $1,2 \%$ \\
\hline Telecommunication services & 1 & $1,2 \%$ \\
\hline Transportation services & 1 & $1,2 \%$ \\
\hline Total & 84 & $100,0 \%$ \\
\hline
\end{tabular}

Source: authorial computation. 
Welc, J.: Empirical Safety Thresholds for Liquidity and Indebtedness Ratios on the Polish Capital Market.

Tab. 2: Time-series distribution of investigated bankruptcy filings

\begin{tabular}{lrr}
\hline Year & $\begin{array}{c}\text { Number of } \\
\text { observations }\end{array}$ & $\begin{array}{c}\text { Share in } \\
\text { a sample }\end{array}$ \\
\hline 2009 & 11 & $13,1 \%$ \\
2010 & 4 & $4,8 \%$ \\
2011 & 5 & $6,0 \%$ \\
2012 & 25 & $29,8 \%$ \\
2013 & 21 & $25,0 \%$ \\
2014 & 10 & $11,9 \%$ \\
First half of 2015 & 8 & $9,5 \%$ \\
\hline Total & $\mathbf{8 4}$ & $\mathbf{1 0 0 , 0 \%}$ \\
\hline
\end{tabular}

Source: authorial computation.

As might be seen, no any individual industry seems to dominate, although two leading businesses make up almost $30 \%$ of investigated bankruptcy filings. It seems therefore that the sample of corporate failures, included in this study, may be considered representative of a broad spectrum of diverse Polish companies. In contrast, a time-series breakdown shows that two years of economic slowdown (2012-2013) seem to be over-represented, while other periods, particularly those featured by relatively fast growth of Polish economy $(2010,2011,2014)$, seem to be under-represented. However, it seems fully logical, because bankruptcy rates tend to rise / fall when macroeconomic conditions deteriorate / improve.

The research was conducted in four steps. First, medians of current ratio and indebtedness ratio within both sub-samples (i.e. bankrupt vs. healthy firms) have been compared and the statistical significance of differences between those medians has been checked (by Wilcoxon Rank-Sum test). Then, two univariate logit models for bankruptcy prediction have been estimated (with current ratio as the only explanatory variable in the first model and indebtedness ratio as the only explanatory variable in the second one). In the third step both logit models have been evaluated in terms of their in-sample prediction accuracy (i.e. an extent to which they correctly classify bankrupt and healthy firms included in the sample). Finally, on the ground of the estimated logit models the generalized safety thresholds for current ratio and total indebtedness ratio have been simulated.

To avoid possible distortions of model parameters, brought about by outlying observations (i.e. companies with unusually high or low values of current and indebtedness ratios), both logit models were estimated on the samples which exclude outliers. In the case of both ratios an inter-quartile range rule has been applied in identifying outliers. However, in the third step of the research (i.e. the 
evaluation of bankruptcy prediction abilities of both logit models) the whole original sample (i.e. including outliers) has been used. In classifying firms as bankrupt or healthy ones, on the ground of both logit models, an arbitrary threshold for bankruptcy probability, equalling 50\%, has been assumed (i.e. any company in which case the probability of bankruptcy, as suggested by the logit model, lies above / below 50\%, has been classified as bankrupt / healthy).

\section{Results and Discussion}

Table 3 presents medians as well as additional statistics computed for both investigated ratios.

\section{Tab. 3: Medians, means and variations of current and indebtedness ratio within sub-samples of bankrupt and healthy firms}

\begin{tabular}{|c|c|c|c|c|}
\hline & \multicolumn{2}{|c|}{$\begin{array}{l}\text { Current ratio (current assets / } \\
\text { current liabilities) }\end{array}$} & \multicolumn{2}{|c|}{$\begin{array}{l}\text { Indebtedness ratio (total } \\
\text { liabilities / total assets) }\end{array}$} \\
\hline & $\begin{array}{l}\text { Bankrupt } \\
\text { firms }\end{array}$ & $\begin{array}{l}\text { Healthy } \\
\text { firms }\end{array}$ & $\begin{array}{c}\text { Bankrupt } \\
\text { firms }\end{array}$ & $\begin{array}{c}\text { Healthy } \\
\text { firms }\end{array}$ \\
\hline Median & 0,88 & 1,61 & 0,75 & 0,47 \\
\hline Arithmetic mean & 1,23 & 3,51 & 0,78 & 0,57 \\
\hline Std. deviation & 1,44 & 10,70 & 0,37 & 0,92 \\
\hline Coef. of variation & $117,7 \%$ & $305,1 \%$ & $47,8 \%$ & $161,1 \%$ \\
\hline $\begin{array}{l}\text { Wilcoxon Rank-Sum test } \\
\text { statistic for the difference } \\
\text { between two medians* }\end{array}$ & \multicolumn{2}{|r|}{5,57} & \multicolumn{2}{|c|}{6,50} \\
\hline
\end{tabular}

Source: authorial computation.

Note: * value above two means that the difference between medians is statistically significant at $5 \%$ significance level.

As expected, bankrupt firms tend to have substantially lower pre-bankruptcy liquidity as well as relatively high pre-bankruptcy indebtedness, as compared to non-bankrupt companies. Wilcoxon Rank-Sum test statistics, which exceed a critical value of two by high margins, confirm that both sub-samples differ significantly in terms of median values of both ratios. The additional statistics inform that both ratios show significant variation not only between bankrupt and healthy firms, but also within both groups of companies (with liquidity having more asymmetrical distribution and probably more outliers than indebtedness).

Table 4 displays parameters of logit models as well as an analysis of the accuracy of their in-sample bankruptcy predictions. Both models are statistically significant (with high values of F-statistics). As expected, slope coefficient is negative for 
Welc, J.: Empirical Safety Thresholds for Liquidity and Indebtedness Ratios on the Polish Capital Market.

current ratio and positive for indebtedness. The prediction accuracy (in the range between $69 \%$ and $73 \%$ ) of both models seems to be surprisingly good, given that both models were estimated on the ground of samples which include firms from diverse industries and given that only one accounting ratio is used as an explanatory variable in each model. At the arbitrarily assumed probability threshold of 50\%, the accuracy of predictions does not differ significantly between bankrupt and non-bankrupt firms (with current ratio being slightly better in identifying healthy firms, while indebtedness being a little bit more accurate in signalling forthcoming bankruptcies).

\section{Tab. 4: Parameters of logit models and analysis of bankruptcy prediction accuracy}

\begin{tabular}{|c|c|c|c|c|}
\hline & \multicolumn{2}{|c|}{$\begin{array}{l}\text { Logit model with current } \\
\text { ratio }\end{array}$} & \multicolumn{2}{|c|}{$\begin{array}{l}\text { Logit model with } \\
\text { indebtedness ratio }\end{array}$} \\
\hline & Coefficient & t-Statistic & Coefficient & t-Statistic \\
\hline Intercept & 2,71 & 5,69 & $-3,38$ & $-6,31$ \\
\hline Slope coefficient & $-2,29$ & $-6,40$ & 5,59 & 6,67 \\
\hline R-squared & \multicolumn{2}{|c|}{0,23} & \multicolumn{2}{|c|}{0,22} \\
\hline F-statistic & \multicolumn{2}{|c|}{41,00} & \multicolumn{2}{|c|}{44,46} \\
\hline Significance of F-statistic & \multicolumn{2}{|c|}{0,0000} & \multicolumn{2}{|c|}{0,0000} \\
\hline $\begin{array}{l}\text { Number of observations, } \\
\text { after removal of outliers }\end{array}$ & \multicolumn{2}{|c|}{$\begin{array}{l}137 \text { ( } 69 \text { bankrupt / } 68 \text { non- } \\
\text { bankrupt) }\end{array}$} & \multicolumn{2}{|c|}{$\begin{array}{l}161 \text { ( } 78 \text { bankrupt / } 83 \text { non- } \\
\text { bankrupt) }\end{array}$} \\
\hline Correctly predicted: bankrupt* & \multicolumn{2}{|c|}{$69,33 \%$} & \multicolumn{2}{|c|}{$71,76 \%$} \\
\hline Correctly predicted: healthy* & \multicolumn{2}{|c|}{$72,84 \%$} & \multicolumn{2}{|c|}{$71,08 \%$} \\
\hline Correctly predicted: total* & \multicolumn{2}{|c|}{$71,15 \%$} & \multicolumn{2}{|c|}{$71,43 \%$} \\
\hline
\end{tabular}

Source: authorial computation.

Note: * within the whole sample of 84 bankrupt and 84 non-bankrupt firms; a threshold of probability of $50 \%$ has been assumed for classification of companies.

Finally, Table 5 presents simulation of generalized safety thresholds (done on the ground of the logit models disclosed in Table 4), meant as values of both accounting ratios at which the probability of company bankruptcy exceeds $50 \%$. As might be seen, the empirically estimated safety thresholds seem to be rather consistent with commonly applied "rules of thumb". To keep a company sustainable, its managers should ensure that carrying amount of liquid (current) assets exceeds carrying amount of short-term liabilities by at least 16-17\%, but preferably by about $30-40 \%$ (to keep the risk of illiquidity significantly lower than $50 \%$ ). Generally speaking, current ratios substantially higher than 1,50 may imply 
temporary over-liquidity (ceteris paribus), while values below unity should be interpreted as strong warning signals about forthcoming bankruptcy filing. In the case of indebtedness, its generalized safety threshold seems to lie near 60-61\%, that is near the "rule of thumb" commonly applied on the Polish market. Its value below 50\% / above 70\% suggests remote / increased risk of insolvency in the course of the following year.

Tab. 5: Simulation of safety thresholds for current ratio and total indebtedness ratio

\begin{tabular}{rr|rr}
\hline \multicolumn{1}{l|}{ Current ratio } & \multicolumn{2}{|l}{ Indebtedness ratio } \\
\hline $\begin{array}{l}\text { Assumed value of } \\
\text { ratio }\end{array}$ & $\begin{array}{l}\text { Probability of } \\
\text { bankruptcy }\end{array}$ & $\begin{array}{l}\text { Assumed value of } \\
\text { ratio }\end{array}$ & $\begin{array}{c}\text { Probability of } \\
\text { bankruptcy }\end{array}$ \\
\hline 0,80 & $87,9 \%$ & 0,30 & $1,9 \%$ \\
0,90 & $81,8 \%$ & 0,40 & $6,7 \%$ \\
1,00 & $72,7 \%$ & 0,50 & $20,6 \%$ \\
$\mathbf{1 , 1 6}$ & $\mathbf{5 0 , 7 \%}$ & $\mathbf{0 , 6 0}$ & $\mathbf{4 8 , 4 \%}$ \\
$\mathbf{1 , 1 7}$ & $\mathbf{4 9 , 4 \%}$ & $\mathbf{0 , 6 1}$ & $\mathbf{5 1 , 6 \%}$ \\
1,30 & $35,3 \%$ & 0,70 & $77,3 \%$ \\
1,40 & $24,4 \%$ & 0,80 & $92,5 \%$ \\
1,50 & $16,0 \%$ & 0,90 & $97,8 \%$ \\
\hline
\end{tabular}

Source: authorial computation.

\section{Conclusion}

In this paper the usefulness of two commonly applied accounting metrics, meaning current ratio and total indebtedness ratio, has been evaluated from the corporate bankruptcy prediction's point of view. The study has been based on real-life data of Polish public companies, in which case at least one bankruptcy filing was announced in the period between the beginning of 2009 and the end of the first half of 2015. This sample of corporate failures has been examined on the background of the counter-sample of randomly selected non-bankrupt firms.

The statistical analysis has confirmed the usefulness of both investigated ratios in a bankruptcy prediction. Even though both empirical sub-samples (i.e. bankrupt and healthy firms) cover wide variety of businesses, the univariate logit models with only one accounting ratio used as an explanatory variable are capable of correctly identifying bankrupt and healthy firms (with one-year-ahead forecast 
Welc, J.: Empirical Safety Thresholds for Liquidity and Indebtedness Ratios on the Polish Capital Market.

horizon) in about $69-73 \%$ of cases. Our research has also shown that the empirically estimated generalized safety thresholds of both ratios lie near the subjective values ("rules of thumb") typically assumed, that is about 1,20 for the current ratio and about 0,60 for the total indebtedness ratio. The obtained empirical findings are therefore relevant for all financial statement users (including stock and bond investors, equity analysts, credit risk analysts and auditors), because they confirm the usefulness of the investigated simple ratios in company's fundamental analysis.

However, this study has some relevant limitations. First of all, the seven-year period covered by the research is pretty short and embraces only few incomplete business cycles. During the years under investigation Polish economy did not experience any single year of recession (i.e. decline of gross domestic product). This means that the results can be somewhat biased. In particular, it is likely that the obtained estimates understate the generalized safety threshold of current ratio and overstate the affordable threshold of indebtedness. It is important qualification because in the case of recession (especially the deep and unforeseen one) the higher share of companies with liquidity and indebtedness ratios lying near the estimated thresholds could go bankrupt and that could significantly change the empirical estimates of those thresholds. Another limitation of the study stems from the fact that the investigated ratios have been computed on the ground of annual reports only, instead of the most recent publicly available information published in quarterly reports. This may reduce the predictive accuracy of the estimated bankruptcy prediction models to some extent.

\section{References}

Atrill, P., 2000. Financial Management for Non-Specialists. Harlow, Pearson Education Limited.

Beaver, W. H., McNichols, M., Rhie, J. W., 2005. Have Financial Statements Become Less Informative? Evidence From the Ability of Financial Ratios to Predict Bankruptcy. Review of Accounting Studies 1, 93-122. DOI: 10.1007/s11142-004-6341-9.

Caouette, J. B., Altman, E. I., Narayanan, P., Nimmo, R. W. J., 2008. Managing Credit Risk. The Great Challenge for Global Financial Markets. Hoboken, John Wiley \& Sons. DOI: 10.1002/9781118266236.

Charalambous, C., Charitou, A., Kaourou, F., 2000. Comparative Analysis of Artificial Neural Network Models: Application in Bankruptcy Prediction. Annals of Operations Research 1, 403-425. DOI: 10.2139/ssrn.251082.

Chava, S., Jarrow, R. A., 2004. Bankruptcy Prediction with Industry Effects. Review of Finance 8, 537-569. DOI: 10.1007/s10679-004-6279-6. 
David, F. R., 2011. Strategic Management. Concepts and Cases. Upper Saddle River, Prentice Hall.

Demerjian, P. R. W., 2007. Financial Ratios and Credit Risk: The Selection of Financial Ratio Covenants in Debt Contracts. AAA 2007 Financial Accounting and Reporting Section (FARS) Meeting Paper. DOI: 10.2139/ssrn.929907.

Fridson, M., Alvarez, F., 2002. Financial Statement Analysis. A Practitioner's Guide. New York, John Wiley \& Sons.

Giroux, G., 2004. Detecting Earnings Management. Hoboken, John Wiley \& Sons. Graham, B., Dodd, D., 1934. Security Analysis. New York, McGraw-Hill.

Ketz, J. E., 2004. Hidden Financial Risk. Understanding Off-Balance Sheet Accounting. Hoboken, John Wiley \& Sons.

Kraft, T., 2015. Rating Agency Adjustments to GAAP Financial Statements and Their Effect on Ratings and Credit Spreads. The Accounting Review 2, 641-674. DOI: $10.2308 /$ accr-50858.

Mackenzie, B., Coetsee, D., Njikizana, T., Chamboko, R., Colywas, B., Hanekom, B., 2012. Interpretation and Application of International Financial Reporting Standards. Hoboken, John Wiley \& Sons.

Montier, J., 2009. Value Investing. Tools and Techniques for Intelligent Investment. Chichester, John Wiley \& Sons. DOI: 10.1002/9781119209195.

Moyer, R.C., McGuigan, J.R., Kretlow, W.J., 1995. Contemporary Financial Management. West Publishing Company, St. Paul.

Ohlson, J. A., 1980. Financial Ratios and the Probabilistic Prediction of Bankruptcy. Journal of Accounting Research 1, 109-131. DOI: 10.2307/2490395.

Palepu, K. G., Healy, P. M., Bernard, V. L., 2004. Business Analysis \& Valuation Using Financial Statements. Mason, Thomson South-Western.

Pratt, S.P., Niculita, A.V., 2008. Valuing a Business. The Analysis and Appraisal of Closely Held Companies. New York, McGraw-Hill.

Revsine, L., Collins, D.W., Johnson, W.B., 2002. Financial Reporting \& Analysis. Prentice Hall, Upper Saddle River.

Robinson, T. R., Henry, E., Pirie, W. L., Broihahn, M. A., 2012. International Financial Statement Analysis. Hoboken, John Wiley \& Sons.

Saliers, E. A., 1924. Accountant's Handbook. New York, The Ronald Press Company. DOI: 10.1002/ncr.4110130611.

Shumway, T., 2001. Forecasting Bankruptcy More Accurately: A Simple Hazard Model. Journal of Business 1, 101-124. DOI: 10.1086/209665.

Stickney, C. P., Brown, P. R., Wahlen, J. M., 2004. Financial Reporting and Statement Analysis. A Strategic Perspective. Mason, Thomson South-Western. 
Welc, J.: Empirical Safety Thresholds for Liquidity and Indebtedness Ratios on the Polish Capital Market.

Verninmen, P., Quiry, P., Dallocchio, M., Le Fur, Y., Salvi, A., 2005. Corporate Finance Theory and Practice. Chichester, John Wiley \& Sons.

Wheelen, T. L., Hunger, J. D., 1995. Strategic Management and Business Policy. New York, Addison Wesley.

White, C., 2004. Strategic Management. New York, Palgrave Macmillan.

White, G. I., Sondhi, A. C., Fried, D., 2003. The Analysis and Use of Financial Statements. Hoboken, John Wiley \& Sons.

Zmijewski, M. E., 1984. Methodological Issues Related to the Estimation of Financial Distress Prediction Models. Journal of Accounting Research 2, 59-82. DOI: $10.2307 / 2490859$. 